passion and prejudice have been more conspicuous than exact knowledge. From Vanderbilt University, Nashville, Tennessee, one of the smaller privately controlled universities of the United States, we have received a volume of abstracts of theses presented during 1933-34 by candidates for advanced degrees and, among them, a study by a candidate for the doctorate of philosophy of a movement for fostering these elements of culture among a 'non-Aryan' group, namely, the American Negro. It seems that since towards the close of the nineteenth century a sustained effort to develop race-conscious feeling so as to achieve "the internal unity and sentimental solidarity necessary to give the race a life more or less separate from other groups" has accompanied a vigorous struggle for recognition and status. Especially in the five years 1910-15, the aims and purposes of the movement became definitely established, a recognised leader emerged and formal machinery for its further promotion was created. At the present time, extensive provision is made by Negro colleges and universities for courses of instruction in Negro life and history, and numerous activities have developed outside the class-room designed to make students better acquainted with Negro tradition: pageants depicting Negro progress and achievement, essay competitions, the celebration of Negro History Week, exhibitions of Negro art and literature and music festivals featuring Negro folk music. By making his history and tradition extensively known outside the community, it is assumed that the Negro will gain a larger measure of recognition and respect from the world at large for his worth and capacity.

\section{History and Uses of Paraffin Wax}

IN his paper read before the Institution of Petro. leum Technologists on December 11, 1934, on the "Utilization of Paraffin Wax and Petroleum Ceresin", Mr. P. G. Higgs outlined the history of petroleum wax from its discovery in 1830 to its production on a commercial scale. Its use for a long time was restricted, since combustibility alone of all its useful properties was universally acknowledged as of market value. Time has shown, however, that paraffin wax can be used in cases where its characteristics of resistance to water, inertness, good electrical properties, etc., are invaluable. Thus to-day, apart from its chief function as an illuminant, it is employed, for example, as a proofing agent for porous materials, in the manufacture of waxed paper and paper boards, as an external coating to wooden receptacles for the preservation of foodstuffs, as an ingredient of polishes and in the electrical industry for insulating purposes. In addition, it is used in the form of an aqueous emulsion in the sizing of paper, as a size in the weaving of cotton, and as a glossing agent in the laundry trade.

Petroleum ceresins, the most recent addition to the range of paraffin waxes, are characterised by a relatively high setting point and micro-crystalline structure. Experiments have shown that the addition of $0 \cdot 3$ per cent or less to commercial paraffin wax alters the structure of the whole practically to micro- crystallinity. Moreover, in the case of candles made from paraffin wax to which a similar small percentage of ceresin has been added, resistance to bending is substantially increased. Initially, the strong colour of petroleum ceresin was a disadvantage in this connexion, but this is overcome by incorporation of the ceresin during the manufacture of the paraffin wax and refining the two together. The resultant product, while having a pleasing colour, also lacks, or has in a much lesser degree, the defects usually consequent on marked crystallinity of the paraffin wax. It is reasonable to suppose, therefore, that the usefulness of paraffin wax could be still further extended by the addition of small quantities of petroleum ceresin. Whether it is better to manufacture 'doped' waxes or leave the 'doping' process to the user is, however, still an open question.

\section{Water Purification by Ozone}

IN Engineering of January 4, Mr. T. Rich gives an account of the development of the treatment of water by ozone which has resulted from the researches made by $P$. Otto in 1898 in connexion with his thesis for a doctor's degree at the Sorbonne. When Dr. Otto was carrying out his experiments, the question of potable water supplies in France was becoming a matter of concern, and, encouraged by Pasteur, he took up the design of ozone water-sterilisation apparatus for outputs varying from that through a single tap to that required for large cities. One of the first important installations laid down to his designs was that for Nice, and since this was constructed many other places on the Riviera have followed the example of Nice, owing to serious outbreaks of typhoid. In 1932, the scientific commission for the study and control of the water supply of Paris decided to supersede the use of chlorine by the use of ozone for treating water taken from the Seine and the Marne, while quite recently an important ozone-sterilisation plant has been put into commission for the water supply of Nancy, a manufacturing city of 120,000 inhabitants. There are other plants in operation in Belgium, Italy, Rumania and on the Congo, and the system has been applied to the water supply of large passenger vessels. The principal apparatus in a plant is the electrically-worked Otto ozone generator, and of this Mr. Rich gives a full description.

\section{Grey and Red Squirrels in England}

IN the report on animal numbers, issued by the Oxford University Bureau of Animal Population at the end of 1934, the director, Mr. A. D. Middleton, states that the evidence from the Bureau's three hundred or so observers in various parts of Great Britain points to another serious increase of the American or Carolina grey squirrel (Sciurus carolinensis, Gmelin) and also an increase of the native British red squirrel (Sciurus leucorous, Kerr) after the setback due to disease outbreaks of a species of Eimeria (Coccidia) noted in 1931. During the last three years, the report points out, the British red squirrel seems to have been steadily regaining 
its former status in most parts of the country and is now commonly seen in many districts where the American grey squirrel is not present. Even within the area occupied by the grey squirrel, red squirrels have frequently been seen during the past two years. The American grey squirrel, after its severe setback in 1931, due mainly to disease, was in comparatively low numbers during 1932 and 1933, but there are now many indications that a period of increase is well on the way. It has gradually extended its range, spreading outwards from the main areas previously occupied (home counties, Midlands, Central Yorkshire, Cheshire, North Wales, Dumbartonshire, Fife and the environs of Bournemouth, Exeter and Edinburgh); several have been found in an isolated wood near Woodbridge, in Suffolk. "Should the numbers increase greatly over this large area," adds Mr. Middleton, "it seems probable that the grey squirrel may become of more serious economic importance than hitherto." The Oxford University Bureau is now extending its national investigations of animal numbers to the Japanese deer (Cervus sika) which have escaped from many English parks and taken to living wild in the woods of the home counties and the south, and of harvest. bugs (Trombidiidae).

\section{Scientific Correspondence of Sir James Smith (1759-1828)}

The main portion of Part 1 of the Catalogue of Manuscripts in the Library of the Linnean Society of London is devoted to the scientific correspondence of the first president of the Linnean Society, and Mr. Warren Dawson has abstracted the more important matters referred to in more than 3,000 letters received by Sir James Edward Smith (1759-1828) (Catalogue of the Manuscripts in the Library of the Linnean Society of London, Part 1. The Smith Papers. The Correspondence and Miscellaneous Papers of Sir James Edward Smith, M.D., F.R.S., First President of the Society. By Warren R. Dawson, F.R.S.E. Pp. 114. London: The Linnean Society, 1934. 10s. net). It is a careful piece of work, the completion of which confers a benefit on all who are interested in the natural history of the period immediately following Linnæus's death, and the transference of his collections to England six years later. The correspondents include many distinguished naturalists both at home and abroad, and some of their letters are valuable documents from the point of view of the history of biology. Sir James Edward Smith was primarily a botanist, but as possessor of Linnæus's collections for about forty-five years he had wide interests as a naturalist. $\mathrm{He}$ was one of the founders of the Linnean Society of London, his co-founders being the Rev. Samuel Goodenough, afterwards Bishop of Carlisle, and Thomas Marsham, an entomologist.

\section{International Aspects of Drug Addiction}

IN the Norman Kerr Memorial Lecture on this subjert published in the January issue of the British Journal of Inebriety, Sir Malcolm Delevingne, late Deputy Permanent Under-Secretary of State and
British representative on the Opium Advisory Committee of the League of Nations, showed that the international treatment of the problem during the last fourteen years has afforded a striking example of what can be accomplished in a difficult field by international co-operation, aided by the machinery of the League of Nations. After a historical sketch of the subject with special reference to the conferences at the Hague and Geneva, he dealt with the present position, showing that a system of control over the export and import trade is in operation, which if universally and effectively adopted is practically watertight. The illicit traffic however still continues to flourish, owing to a resort having been made to clandestine sources of supply or to parts of the world where control is less strict or nonexistent. In dealing in conclusion with the medical and scientific aspects of the problem, Sir Malcolm briefly alluded to the treatment and after-care of the addict, the possibility of replacing the drugs wholly or partly by less dangerous substances, the rate of consumption of the drugs in different countries, and the question as to whether new drugs are habitforming or not.

\section{Engineering Research in Japan}

IN vols. 10 and 11 of the Japanese Journal of Engineering recently issued by the National Research Council of Japan (Imperial Academy House, Veno Park, Tokyo), abstracts of varying length are given of some 400 papers on civil engineering, naval architecture, technology of ordnance, electrical engineering, mine engineering and metallurgy. The abstracts are printed in English, and about three-quarters of them relate to various aspects of electrical engineer. ing. Some of the papers have been contributed to the Institution of Electrical Engineers of Japan, while others contain reports of researches carried out at the Electrotechnical Laboratory, Ministry of Communications, Tokyo, and at research institutions and universities. Corresponding journals issued by the National Research Council contain abstracts of papers on astronomy, chemistry, physics, botany, zoology and other branches of science.

\section{Contour Maps of the East}

Among the latest additions to Bartholomew's General World Series are maps of the Middle East (Persia, Iraq, Palestine, Syria, Turkey and North Arabia) and the Far East (China, Japan, Korea and Manchukuo) on scales respectively of $I: 4,000,000$ and $1: 6,000,000$. The maps are contoured and layercoloured in green, brown and purple. Political and provincial boundaries are clearly marked, and on the map of the Middle East the chief roads, routes and caravan tracks are shown, as well as airports. All railways and the principal steamer routes are given. The scale allows a considerable amount of detail and a large number of names. The printing is clear, and the maps should prove most useful. The price of each map mounted on cloth and folded is six shillings. 